\title{
Selective inhibition of $\gamma$-aminobutyric acid type A receptors in human IMR-32 cells by low concentrations of toluene
}

\author{
Cécil J.W. Meulenberg, Henk P.M. Vijverberg* \\ Institute for Risk Assessment Sciences (IRAS), Utrecht University, P.O. Box 80176, NL-3508 TD Utrecht, The Netherlands
}

Received 10 March 2003; accepted 30 April 2003

\begin{abstract}
Effects of the neurotoxic organic solvent toluene on human neuronal nicotinic acetylcholine (nACh) and $\gamma$ aminobutyric acid type $\mathrm{A}\left(\mathrm{GABA}_{\mathrm{A}}\right)$ neurotransmitter receptors were investigated in whole-cell voltage-clamped IMR32 neuroblastoma cells. Ion currents evoked by near maximum effective concentrations of $1 \mathrm{mM}$ acetylcholine (ACh) and $1 \mathrm{mM} \gamma$-aminobutyric acid (GABA) are inhibited by toluene in a concentration-dependent way. Concentrationeffect curves of toluene yield $\mathrm{IC}_{50}$ values of $276 \pm 26$ and $39 \pm 6 \mu \mathrm{M}$ and slope factors of $1.4 \pm 0.2$ and $0.8 \pm 0.1$ for inhibition of the ACh- and GABA-induced ion currents, respectively. The results demonstrate the selective inhibition of human $\mathrm{GABA}_{\mathrm{A}}$ receptors by toluene at concentrations comparable with brain concentrations associated with occupational exposure.
\end{abstract}

(C) 2003 Elsevier Ireland Ltd. All rights reserved.

Keywords: Human neuroblastoma cells; $\mathrm{GABA}_{\mathrm{A}}$ receptor; Neuronal nicotinic ACh receptor; Toluene

\section{Introduction}

Exposure to toluene, a major constituent of organic solvent mixtures, has been associated with a variety of neurotoxic effects ranging from subtle alterations in neurobehavioral parameters to gross neuropathological changes (for review see Schaumburg, 2000). Acute exposure to high levels of toluene by abusive inhalation of solvents induces central nervous system excitation followed by depression (Balster, 1998). While the central

* Corresponding author. Tel.: +31-30-2535397; fax: +3130-2535077.

E-mail address: h.vijverberg@iras.uu.nl (H.P.M. Vijverberg). nervous system is regarded to be the primary target organ of toluene toxicity, the mechanisms by which toluene exerts its complex neurotoxic effects remain to be established.

Neuronal activity recorded from various rodent brain slices showed increased neuronal activity at micromolar and sub-millimolar concentrations of toluene (Ikeuchi et al., 1993; Beckstead et al., 2000; Riegel and French, 2002). In addition, higher concentrations of toluene produced a pronounced inhibition in brain slices (Ikeuchi et al., 1993; Magnusson et al., 1998; Riegel and French, 2002). In vivo administration of toluene to rats produced a dose-dependent locomotor hyperactivity, which was attenuated by the dopamine $\mathrm{D}_{2}$ receptor antagonist remoxipride (Riegel and French, 
2002). These authors further suggested that the effects within the ventral tegmental area may underlie the abusive potential of toluene.

The fine-tuning of in vivo systems such as dopaminergic pathways hinders the elucidation of a specific molecular target for toluene. However, possible targets have been put forward by in vitro studies. In rat PC-12 cells, toluene $(30-300$ $\mu \mathrm{M})$ evoked vesicular catecholamine release induced by an influx of extracellular $\mathrm{Ca}^{2+}$ through voltage-activated $\mathrm{Ca}^{2+}$-channels (Westerink and Vijverberg, 2002). Studies of receptors, heterologously expressed in Xenopus oocytes, show that millimolar concentrations of toluene inhibit various heteromeric types of rat $N$-methyl-D-aspartate (NMDA) type but not $\alpha$-amino-3-hydroxy-5methylisoxazole-4-propionic acid (AMPA)/kainate type glutamate receptors (Cruz et al., 1998). Toluene $(420 \mu \mathrm{M})$ has also been reported to potentiate responses mediated by human $\gamma$-aminobutyric acid type $\mathrm{A}\left(\mathrm{GABA}_{\mathrm{A}}\right)$ and glycine receptors expressed in oocytes (Beckstead et al., 2000). The potentiating effect on $\mathrm{GABA}_{\mathrm{A}}$ receptors is associated with a small left shift of the GABA concentration-effect curve (Beckstead et al., 2000). However, effects of toluene on receptors natively expressed in cell systems are lacking.

Human IMR-32 neuroblastoma cells express multiple neuronal nicotinic acetylcholine (nACh) receptor subunits $(\alpha 3, \alpha 4, \alpha 5, \alpha 7, \beta 2$, and $\beta 4$; Groot-Kormelink and Luyten, 1997) and $\mathrm{GABA}_{\mathrm{A}}$ receptor subunits $(\alpha 1, \alpha 3, \alpha 4, \beta 1, \beta 3, \gamma 2$, and $\delta$; Noble et al., 1993), resulting in heterogeneous populations of functional $\mathrm{nACh}$ receptors (Gotti et al., 1995) and $\mathrm{GABA}_{\mathrm{A}}$ receptors (Sapp and Yeh, 2000). Here, we report effects of toluene on $\mathrm{GABA}_{\mathrm{A}}$ and $\mathrm{nACh}$ receptors native to IMR-32 human neuroblastoma cells.

\section{Methods}

\subsection{Cell cultures}

IMR-32 cells (ATCC \#CCL-127) were cultured, at $37{ }^{\circ} \mathrm{C}$ in a humidified atmosphere containing $5 \%$ $\mathrm{CO}_{2}$, in $\alpha$-minimum essential medium supplemented with $10 \%$ heat-inactivated fetal calf serum, 100 units $\mathrm{ml}^{-1}$ penicillin, $100 \mu \mathrm{g} \mathrm{ml}^{-1}$ streptomycin, and $1 \%$ non-essential amino acids. Cells were plated in $25 \mathrm{~cm}^{2}$ plastic tissue culture flasks $(6 \times$ $10^{5}$ cells per flask). After 7 days, cells were harvested and subcultured in $35 \mathrm{~mm}$ diameter dishes $\left(16 \times 10^{3}\right.$ cells per dish). Flasks and dishes were coated with mouse collagen type IV. The culture medium was refreshed every 2-3 days. Cells were used for experiments starting from 3 days after subculture.

\subsection{Solutions}

External solution contained (in $\mathrm{mM}$ ): $125 \mathrm{NaCl}$; $5.5 \mathrm{KCl} ; 1.8 \mathrm{CaCl}_{2} ; 0.8 \mathrm{MgCl}_{2} ; 20$ HEPES; 25 glucose; and 36.5 sucrose (pH 7.3 with $\mathrm{NaOH}$ ). The pipette solution contained (in $\mathrm{mM}$ ): $20 \mathrm{NaCl}$; $50 \mathrm{KCl} ; 70 \mathrm{~K}$-gluconate; $6 \mathrm{MgSO}_{4} ; 5$ EGTA; 0.25 $\mathrm{CaCl}_{2} ; 10$ HEPES; and $5 \mathrm{Na}_{2} \mathrm{ATP}$ (pH 7.2 with $\mathrm{KOH})$. Stock solutions of $1 \mathrm{M}$ acetylcholine (ACh) chloride and $0.5 \mathrm{M} \gamma$-amino- $n$-butyric acid (GABA) in distilled water were kept frozen at $-20{ }^{\circ} \mathrm{C}$ until use. Toluene $(97.7 \%)$ was dissolved in $100 \mathrm{ml}$ of external solution by overnight stirring in a tightly closed glass bottle to produce a saturated stock solution $(6.3 \mathrm{mM}$ in water; Eastcott et al., 1988). Aliquots of stock solutions of $\mathrm{ACh}, \mathrm{GABA}$, and toluene were mixed with external solution immediately before the experiments.

\subsection{Voltage-clamp}

IMR-32 cells were voltage-clamped at $-80 \mathrm{mV}$ in the whole-cell configuration (Hamill et al., 1981) using an EPC-7 patch-clamp amplifier and borosilicate glass patch pipettes with a resistance of 3-6 $\mathrm{M} \Omega$. The liquid junction potential was compensated before each experiment and remained constant within $1 \mathrm{mV}$. Experiments were performed at room temperature $\left(21-23{ }^{\circ} \mathrm{C}\right)$.

\subsection{Cell superfusion}

Voltage-clamped cells were continuously superfused through a glass capillary with a diameter of 1 $\mathrm{mm}$ positioned within $0.5 \mathrm{~mm}$ from the cell with external solution $\left(1.5 \mathrm{ml} \mathrm{min}{ }^{-1}\right)$ with or without 
agonists and toluene for adjustable periods using a servomotor-operated valve. Between successive $\mathrm{ACh}$ or GABA responses cells were washed with external solution for $4 \mathrm{~min}$ to reverse receptor desensitization. To avoid cumulative effects, cells were exposed to a single concentration of toluene only.

\subsection{Data analysis}

Membrane currents were low-pass filtered (Bessel, 8 pole, $-3 \mathrm{~dB}$ at $300 \mathrm{~Hz}$ ), digitized (12 bits; 1024 points/30 s record), and stored on disc for off-line analysis. Peak amplitudes of ion currents in the presence of toluene were normalized to the average peak amplitude of control responses evoked before application and after washout of toluene. Concentration-effect curves were fitted by nonlinear regression using SigmaPlot 5.0 software.

\section{Results}

Superfusion of voltage-clamped IMR-32 cells with $1 \mathrm{mM} \mathrm{ACh}$, a near maximum effective agonist concentration for $\mathrm{nACh}$ receptors, generally induced a transient inward current. Effects of toluene were investigated on cells with a sufficiently large initial peak inward current amplitude (range 88-330 pA with a median value of $153 \mathrm{pA}$; $n=18$ ). Cells were superfused with an external solution containing 30-3000 $\mu \mathrm{M}$ toluene for 3-4 min before applying ACh together with toluene. Toluene reduced the amplitude of ACh-induced current starting at a concentration of $100 \mu \mathrm{M}$ and the inhibition was half-maximal at about $300 \mu \mathrm{M}$ and was nearly complete at $1000 \mu \mathrm{M}$ toluene. The effect of toluene rapidly reached equilibrium and was readily reversed by washing with external solution (Fig. 1A). Analysis of ACh-induced ion currents before, during, and after the exposure to toluene showed that toluene does not cause detectable changes in the kinetics of the AChinduced ion current. This is illustrated by the superimposed traces in Fig. 1A.

On superfusion of $1 \mathrm{mM}$ GABA, a near maximum effective agonist concentration for GABA receptors in IMR-32 cells, less than $10 \%$ of the cells responded with a transient inward current $\geq$ $100 \mathrm{pA}$. Many cells showed currents $\leq 50 \mathrm{pA}$ and in few cells GABA application did not induce a detectable inward current. The peak amplitudes of GABA responses in the cells selected to investigate the effects of toluene ranged from 49 to $616 \mathrm{pA}$ with a median value of $254 \mathrm{pA}(n=16)$. Like $\mathrm{nACh}$ receptor-mediated inward current, toluene rapidly inhibited $\mathrm{GABA}_{\mathrm{A}}$ receptor-mediated inward current and the effect rapidly reversed on washing with external solution. Toluene causes a measurable inhibition of the GABA responses in IMR-32 cells already at a concentration of $10 \mu \mathrm{M}$, and the GABA-induced inward current was 50\% inhibited by $30 \mu \mathrm{M}$ toluene (Fig. 1B). The superposition of the control currents and those recorded in the presence of toluene (Fig. 1B) show that toluene did not measurably affect the kinetics of GABA-induced inward currents.

The concentration-effect curves of the inhibitory effects of toluene on ACh- and GABAinduced inward currents are shown in Fig. 2. Both curves were obtained from fitting the data on the effects of five different concentrations of toluene each of which was tested on 3-5 different cells. The concentration-effect curve fitted to the data obtained with ACh yielded an $\mathrm{IC}_{50}$ of $276 \pm$ $26 \mu \mathrm{M}$ toluene and a Hill coefficient of $1.4 \pm 0.2$ (mean \pm SE of fit). From the concentration-effect curve for the inhibition of GABA-induced inward currents, an $\mathrm{IC}_{50}$ of $39 \pm 6 \mu \mathrm{M}$ toluene and a Hill coefficient of $0.8 \pm 0.1$ were obtained. Fig. 2 demonstrates that toluene inhibits $\mathrm{GABA}_{\mathrm{A}}$ receptor-mediated inward current in IMR-32 cells with a seven times higher potency than that to inhibit nACh receptor-mediated inward current.

\section{Discussion}

The results show that the human $\mathrm{GABA}_{\mathrm{A}}$ receptors natively expressed in IMR-32 neuroblastoma cells are almost one order of magnitude more sensitive than the human nACh receptors expressed in the same cell line. The presently found 
A
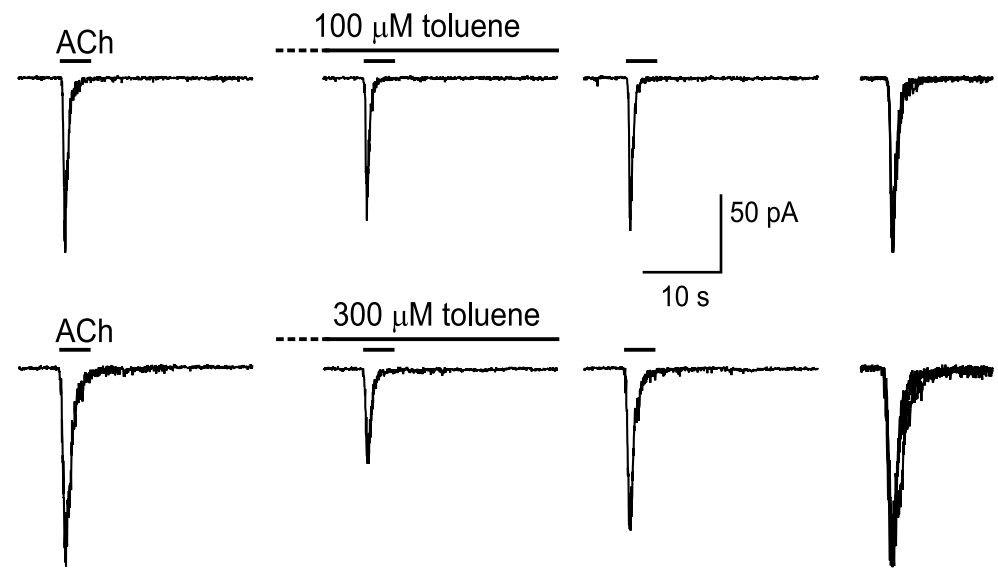

\section{control}

toluene

wash superimposed

\section{$B$}
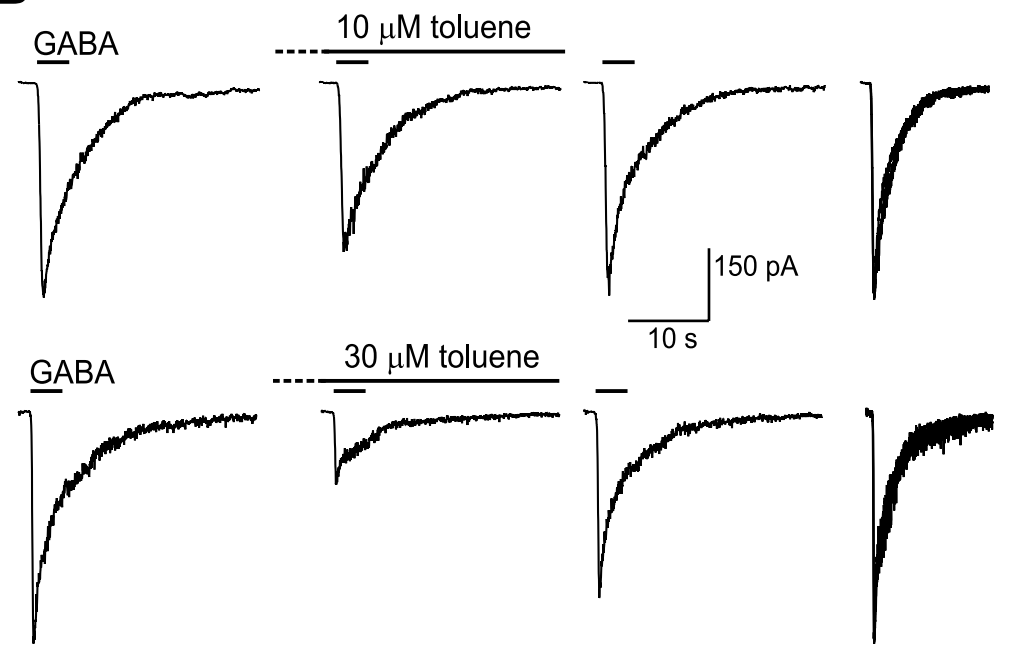

Fig. 1. Toluene inhibits $\mathrm{nACh}$ receptor-mediated ion currents and $\mathrm{GABA}_{\mathrm{A}}$ receptor-mediated ion currents in human IMR-32 cells. (A) Traces illustrating the effect of $100 \mu \mathrm{M}$ toluene and of $300 \mu \mathrm{M}$ toluene on $1 \mathrm{mM}$ ACh-evoked inward current. (B) Traces illustrating the effect of $10 \mu \mathrm{M}$ toluene and of $30 \mu \mathrm{M}$ toluene on $1 \mathrm{mM}$ GABA-evoked inward current. Each set of traces represents the control inward current evoked before the application of toluene, the current in the presence of toluene, at the concentration indicated and the reversal of the effect of toluene by washing with external solution in the same cell. The fourth column shows the control current and superimposed the current in the presence of toluene scaled to the same amplitude. The superimposed traces demonstrate the absence of effects of toluene on kinetics. Note that the superimposed responses in (A) have been enlarged horizontally.

threshold effect for the inhibition of GABAinduced ion current in IMR-32 cells of $10 \mu \mathrm{M}$ toluene shows that the human $\mathrm{GABA}_{\mathrm{A}}$ type receptors are the more sensitive target of this neurotoxic solvent presently known. Analogous to other neurotoxic agents, e.g., heavy metals (Vijverberg et al., 1994), toluene may exert multiple, selective effects on neuronal signaling. In this 


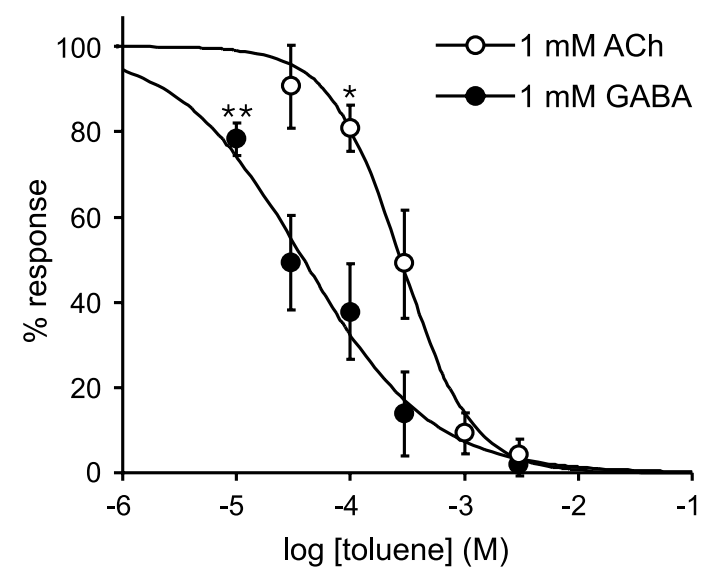

Fig. 2. Concentration-effect curves for the inhibition of AChand GABA-induced ion currents by toluene. Each point represents the mean relative inhibition $( \pm$ S.D. bar $)$ obtained from three to five cells. Concentration-effect curves, fitted according to the Hill equation, yield $\mathrm{IC}_{50}$ values of $276 \mu \mathrm{M}$ for $\mathrm{nACh}$ receptors and $39 \mu \mathrm{M}$ for $\mathrm{GABA}_{\mathrm{A}}$ receptors. Significant inhibition is observed at $\geq 100 \mu \mathrm{M}$ toluene (two-tailed $t$-test, $P=0.03)$ for $\mathrm{nACh}$ receptors and at $\geq 10 \mu \mathrm{M}$ toluene $(P=$ 0.01 ) for $\mathrm{GABA}_{\mathrm{A}}$ receptors.

respect, it is interesting to note that the hypothesis that neuronal degeneration may relate to the potential of agents to disturb the balance of excitation and inhibition in interrelated glutamatergic and GABA-ergic pathways in the central nervous system (Olney et al., 2000) is beginning to find support from experimental evidence.

The advantage of IMR-32 cells is that they express native human neurotransmitter receptors. However, multiple nACh receptor and $\mathrm{GABA}_{\mathrm{A}}$ receptor subtypes are expressed (see Section 1), which is a confounding factor for mechanistic studies. The shallow slope of the concentrationeffect curve for inhibition of GABA-induced ion current (Fig. 2) may be due to the presence of a heterogeneous population of $\mathrm{GABA}_{\mathrm{A}}$ receptors with slightly different sensitivities to inhibition by toluene. The steep slope of the concentrationeffect curve for inhibition of ACh-induced ion current indicates that $\mathrm{nACh}$ receptors expressed in IMR-32 cells have a similar sensitivity to inhibition by toluene. The inhibitory effect of toluene on natively expressed human $\mathrm{GABA}_{\mathrm{A}}$ receptors, presented here, contrasts with the potentiation of human $\mathrm{GABA}_{\mathrm{A}}$ receptors, heterologously ex- pressed in Xenopus oocytes, by $420 \mu \mathrm{M}$ toluene (Beckstead et al., 2000). Although the $\mathrm{GABA}_{\mathrm{A}}$ receptor subunits studied in oocytes $(\alpha 1, \beta 1$, and $\gamma 2_{\mathrm{L}}$ ) are also expressed in IMR-32 cells (see Section 1), it is unknown which specific receptor subtypes mediate GABA-induced ion current in IMR-32 cells. Whether an inhibitory effect of toluene on the $\mathrm{GABA}_{\mathrm{A}}$ receptors is involved in the potent enhancement of the amplitude of the population spike of guinea pig hippocampal granule cells (Ikeuchi et al., 1993) and in producing the hyperactivity of neurons within the ventral tegmental area (Riegel and French, 2002) also remains to be established. Some of these questions might be answered by systematically investigating the subunit and species dependence of toluene effects on $\mathrm{GABA}_{\mathrm{A}} / \mathrm{nACh}$ receptors. However, presynaptic effects of toluene leading to neurotransmitter release (Westerink and Vijverberg, 2002) might contribute to neurotoxic effects induced by toluene.

Human exposure to ambient air levels of 33-66 ppm toluene for 7-8 h leads to venous blood concentrations of 5-14 $\mu \mathrm{M}$ toluene (Laparé et al., 1993). These exposure levels are similar to the current time-weighted-average threshold limit value (TWA-TLV) of $50 \mathrm{ppm}$ toluene (Schaumburg, 2000). Acute occupational intoxication is associated with blood concentrations of $9-44 \mu \mathrm{M}$ toluene (Brugnone et al., 1983; Meulenbelt et al., 1990) and acute intoxication caused by glue sniffing may be associated with blood concentrations as high as $90 \mu \mathrm{M}$ toluene (King, 1982). Since the human brain:blood partition coefficient of toluene is close to 3 (Fiserova-Bergerova et al., 1984), prolonged exposure to toluene will lead to proportionally higher brain concentrations. Thus, the present results show that human $\mathrm{GABA}_{\mathrm{A}}$ receptor function will be reduced under conditions of occupational exposure to toluene at ambient air levels not exceeding the current regulatory limits. However, a causal relation between neurologic effects of toluene and GABA receptor function has not been established and effects observed on exposure to high levels of toluene may involve multiple targets within and outside the nervous system. 


\section{Acknowledgements}

We thank Gina van Kleef for expertise and assistance in cell culture. This investigation was financially supported by the Dutch Platform for Alternatives to Animal Testing (PAD) grant 95-03.

\section{References}

Balster, R.L., 1998. Neural basis of inhalant abuse. Drug Alcohol Depend. 51, 207-214.

Beckstead, M.J., Weiner, J.F., Eger, E., II, Gong, D.H., Mihic, S.J., 2000. Glycine and $\gamma$-aminobutyric $\operatorname{acid}_{\mathrm{A}}$ receptor function is enhanced by inhaled drugs of abuse. Mol. Pharmacol. 57, 1199-1205.

Brugnone, F., Perbellini, L., Apostoli, P., Locatelli, M., Mariotto, P., 1983. Decline of blood and alveolar toluene concentration following two accidental human poisonings. Int. Arch. Occup. Environ. Health 53, 157-165.

Cruz, S.L., Mirshahi, T., Thomas, B., Balster, R.L., Woodward, J.J., 1998. Effects of the abused solvent toluene on recombinant $N$-methyl-D-aspartate and non- $N$-methyl-Daspartate receptors expressed in Xenopus oocytes. J. Pharmacol. Exp. Ther. 286, 334-340.

Eastcott, L., Shiu, W.Y., Mackay, D., 1988. Environmentally relevant physical-chemical properties of hydrocarbons: a review of data and development of simple correlations. Oil Chem. Pollut. 4, 191-206.

Fiserova-Bergerova, V., Tichy, M., DiCarlo, F.J., 1984. Effects of biosolubility on pulmonary uptake and disposition of gases and vapors of lipophilic chemicals. Drug Metab. Rev. $15,1033-1070$.

Gotti, C., Briscini, L., Verderio, C., Oortgiesen, M., Balestra, B., Clementi, F., 1995. Native nicotinic acetylcholine receptors in human IMR-32 neuroblastoma cells: functional, immunological and pharmacological properties. Eur. J. Neurosci. 7, 2083-2092.

Groot-Kormelink, P.J., Luyten, W.H.M.L., 1997. Cloning and sequence of full-length cDNAs encoding the human neuronal nicotinic acetylcholine receptor (nAChR) subunits $\beta 3$ and $\beta 4$ and expression of seven $\mathrm{nAChR}$ subunits in the human neuroblastoma cell line SH-SY5Y and/or IMR-32. FEBS Lett. 400, 309-314.
Hamill, O.P., Marty, A., Neher, E., Sakmann, B., Sigworth, F.J., 1981. Improved patch-clamp techniques for highresolution current recording from cells and cell-free membrane patches. Pflugers Arch. 391, 85-100.

Ikeuchi, Y., Hirai, H., Okada, Y., Mio, T., Matsuda, T., 1993. Excitatory and inhibitory effects of toluene on neural activity in guinea pig hippocampal slices. Neurosci. Lett. $158,63-66$

King, M.D., 1982. Neurological sequelae of toluene abuse. Hum. Toxicol. 1, 281-287.

Laparé, S., Tardif, R., Brodeur, J., 1993. Effect of various exposure scenarios on the biological monitoring of organic solvents in alveolar air. I. Toluene and $m$-xylene. Int. Arch. Occup. Environ. Health 64, 569-580.

Magnusson, A.K., Sulaiman, M.R., Dutia, M.B., Tham, R., 1998. Effects of toluene on tonic firing and membrane properties of rat medial vestibular nucleus neurones in vitro. Brain Res. 779, 334-337.

Meulenbelt, J., de Groot, G., Savelkoul, T.J.F., 1990. Two cases of acute toluene intoxication. Br. J. Ind. Med. 47, 417-420.

Noble, P.J., Anderson, S.M.P., DeSouza, R.J., Cross, A.J., Stephenson, F.A., 1993. Identification of the $\mathrm{GABA}_{\mathrm{A}}$ receptor $\alpha 3$ subunit in the IMR-32 neuroblastoma cell line. J. Neurochem. 61, 752-755.

Olney, J.W., Farber, N.B., Wozniak, D.F., Jevtovic-Todorovic, V., Ikonomidou, C., 2000. Environmental agents that have the potential to trigger massive apoptotic neurodegeneration in the developing brain. Environ. Health Perspect. 108 (S3), 383-388.

Riegel, A.C., French, E.D., 2002. Abused inhalants and central nervous reward pathways: electrophysiological and behavioral studies in the rat. Ann. NY Acad. Sci. 965, 281-291.

Sapp, D.W., Yeh, H.H., 2000. Heterogeneity of $\mathrm{GABA}_{\mathrm{A}}$ receptor-mediated responses in the human IMR-32 neuroblastoma cell line. J. Neurosci. Res. 60, 504-510.

Schaumburg, H.H., 2000. Toluene. In: Spencer, P.S., Schaumburg, H.H., Ludolph, A.C. (Eds.), Experimental and Clinical Neurotoxicology. Oxford University Press, New York, pp. 1183-1189.

Vijverberg, H.P.M., Oortgiesen, M., Leinders, T., van Kleef, R.G.D.M., 1994. Metal interactions with voltage- and receptor-activated ion channels. Environ. Health Perspect. 102 (S3), 153-158.

Westerink, R.H.S., Vijverberg, H.P.M., 2002. Toluene-induced, $\mathrm{Ca}^{2+}$-dependent vesicular catecholamine release in rat PC12 cells. Neurosci. Lett. 326, 81-84. 